\title{
Non-palatable Medicinal Plants as a Solution to Crop Raiding by Wild Herbivores around Protected Areas
}

\author{
Poorva Joshi, Prof. Milind Watve
}

Poorva Joshi is a founder and director of Bioconcepts, a firm working in the area of medicinal plant conservation, conservation zones in urban fringes, training and consulting. She is an advisor and consultant for the projects for Forest department education, research and wildlife wing. She is a collaborator and consultant to Maharashtra Gene Bank Programme at IISER, Pune . She is working as a Research scientist for Biome conservation foundation, Pune. Email: bioconcepts.pune@gmail.com

Prof. Milind Watve is Professor, Biology, Indian Institute of Science Education and Research, Pune, and Senior scientist and researcher in Evolutionary Biology, Ecology, Human Biology, Biomedicine and Behavioral science. He has 6 patents to his credit and published over 70 research papers as well as popular science books. He is a Fellow, Indian Academy of Sciences, Indian National Science Academy.

\begin{abstract}
The Tadoba-Andhari Tiger Reserve (TATR) is an important nature conservation area for the country having a good population of wild animals. However, on the fringes of this national park, there are issues of human-wildlife conflict such as crop raiding by wild animals, which is an underestimated problem. The constant threat of crop predators and perceived loss in crop produce has discouraged agriculture in close vicinity of the park. Farming is the main livelihood for the people living near TATR, therefore it is an urgent need to keep under review the alternative options that can contribute to farmers' welfare. Considering the developing medicinal plant demand, there is potential in cultivating non-palatable traded medicinal plant species that are resistant to crop-raiding by wildlife. The paper suggests such a model for farmers. We focus on research, awareness, motivation, facilitation and establishing market linkages.
\end{abstract}

\section{Introduction}

Agriculture plays a vital role in India's economy. Over 58 per cent of the rural households depend on agriculture as their principal means of livelihood, our study area adjoining Tadoba Andhari Tiger Reserve (TATR) not being an exception. But at the same time, agricultural lands close to protected areas (PAs) often face crop raiding by wild herbivores, which is a serious problem for farmers whose livelihoods depend on agricultural produce $(1,2,3,4)$. In order to avoid economic loss, farmers apply a range of protective measures. They include manual guarding, various types of fences, trenches and other devices. However, these measures often come with high associated costs and risks $(5,6,7)$. The traditional fences are made using wooden poles and thorny branches lopped from nearby forests causing substantial damage to the forest. Destructive measures such as traps can kill or injure animals. Highly sophisticated means such as electric fences are expensive and need contin- ued maintenance. Although a number of measures have been developed they seem to be failing at some or the other point of time (8). The traditional practices which generally keep raiding at bay and even culling are not advisable to avoid this conflict.

Compensating for loss is practised in India but the compensation amount given to victims is often inadequate $(7,8)$ and hence management of wildlife is increasingly losing its harmony with local people (10). We still need to discover and implement ideas for fringe area management through various relevant means of livelihood which will positively contribute towards conservation. When we already know that management in such projects needs conservation with a focus on community participation, then changing their attitude toward it is of great significance. There is a positive link between the pertinent knowledge and attitudes to conservation $(12,13,14)$. Consequently, it becomes self-evident to build interventions that raise awareness about conservation strategies. Strategies like medicinal plant based alternative liveli- 
hood will amplify the knowledge and behavioural attitudes of the existing livelihood strategies (12).

The newly implemented restrictions on non-agricultural land use in the buffer area are likely to further worsen the conflict $(22,25)$. The aim behind such restrictions is no doubt to promote coexistence between wildlife and human activity, with due recognition of livelihood, developmental, social and cultural rights of the local people. But now with many other options being cut off, alternative farm-based livelihoods need to be explored as a promising and workable option for these communities $(1,4)$. Medicinal plants have the potential to contribute to output growth of agriculture in rural areas. Agriculture based additional livelihood generation will be important to achieve desirable quality of life for farmers. Executing such plantation of medicinal plants could intensify the introduction of simple new application-based technologies, which will have access to new markets $(13,16,17,18)$. For example, if farmers in such areas grow Tulsi plants, which is a non-palatable medicinal plant species, followed by a very simple value addition technique (i.e. drying) and with due training if they follow herbal infusion packing processes, it can directly contribute to their livelihood generation thanks to all the tourists visiting national parks who can become customers for such products.

Therefore, we felt that improving of existing livelihoods should be dealt in an innovative way. Considering the need for conservation and sustainability in the medicinal plants sector, a solution that combined both of these would be ideal. We initiated development of short-scale market strategies followed by training sessions for local people in this region. Diversification of such marketing strategies and their expansion at a larger scale was emphasized during the project period. Formation of a co-operative society of these communities can lead them towards fetching beneficial opportunities. They can achieve this through the National Medicinal Plant Board and other promotional schemes. Such livelihood creation, if linked to the co-operative groups will be a win-win model for local farmers.

\section{Study area and relevance}

Tadoba Andhari Tiger Reserve in Chandrapur district of Maharashtra state in central India is one of the 47 Project Tiger reserves in India. It is situated approximately $150 \mathrm{~km}$ south of Nagpur city. It was declared as a National Park in 1955. Tadoba National Park (116.55 Sq. Kms.) and Andhari wildlife sanctuary (508.85 Sq. Kms.) together form the Tadoba-Andhari
Tiger Reserve. 625.82 sq. $\mathrm{km}$. is the extent of the core area. In addition there is $1101.77 \mathrm{sq} . \mathrm{km}$. of buffer area. The total legal area of the tiger reserve is $1727.59 \mathrm{~km} 2$. (Source: Website of NTCA).

There are over 79 villages in and around this tiger reserve. Villages along the western boundary of Tadoba Andhari Tiger Reserve, Chandrapur, Maharashtra including Ashta, Mudholi, Chandankheda, Vadala, Viloda were the focus of our study. The research site is shown in Figure 1.

The primary occupation for people in these fringe villages is agriculture. The agriculture is monsoon dependent. Although the rainfall is high, it is erratic and affects crop productivity. Under a traditional agricultural system composed of two separate seasons, namely kharif (monsoon crops) and rabi (winter crops), the following crops are grown here: Rice (Oryza sativa) and soybean (Glycine max) are the primary kharif crops whereas wheat (Triticuma estivum) and chickpea (Cicerarie tinum) are primary rabi crops. Apart from these, cotton (Gossypium arboreum), turmeric (Curcuma longa), flax or linseed (Linum usitatissimum), and grass pea or sweet blue pea (Lathyrus sativa) are other secondary crops taken to a lesser extent (8).
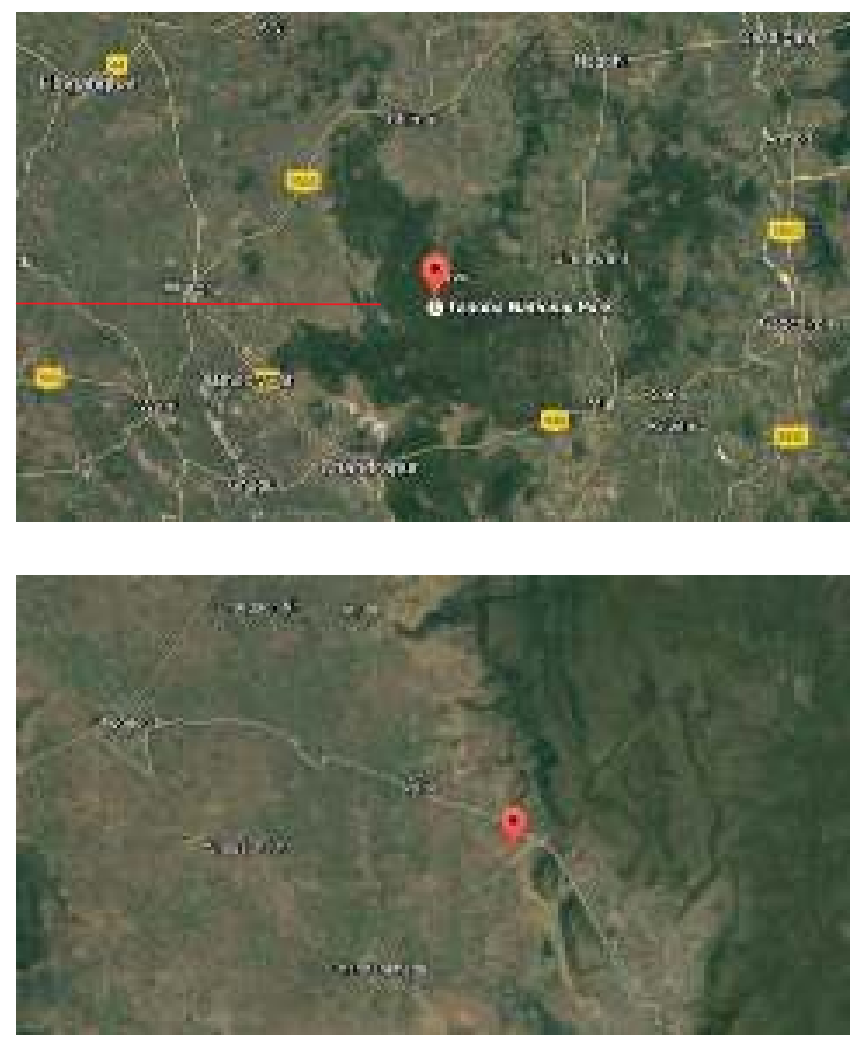

Figure 1 : Study Area 


\section{The study}

Our current study is based on the background of a study conducted by a research team from IISER, Pune on crop raiding by wild animals along the western boundaries of TATR $(9,10)$.

The study comprised of four phases :

- Phase 1 : Selection of species

- Phase 2: Trial plantation

- Phase 3: Techniques for value addition and investment scenario

- Phase 4 : Market linkages

\section{Phase 1 : Selection of species}

Selection of species for propagation was done with the criteria of growth, minimum care, and non-palatable to herbivores. These species are as follows:
1. Cymbopogon Sp. (Citronella and Gavati chaha)

2. Stevia rebaudiana (Candy leaf/Sweet leaf/Stevia)

3. Andrographis paniculata (Kalmegh)

4. Asparagus racemosus (Shatavari)

5. Cassia angustifolia (Sonamukhi)

6. Withania somnifera (Ashwagandha)

7. Oscimum sanctum (Tulsi)

8. Cissus quadrangularis (Hadjodi)

9. Vetiveria zizanioides (Vala)

10. Acorus calamus (Vekhand)

\section{Phase 2 : Trial plantation of 10 species}

We tried to grow selected medicinal plants which are in high trade in the study area to test their suitability for the soil and climatic conditions. Some of these can give yield year around and others with a short crop-like life cycle.

Table 1 : Economics of select plant crops

\begin{tabular}{|l|l|l|l|l|}
\hline Name of crop & Kalmegh & Tulsi & Vekhand & Stevia \\
\hline Type of crop & One time & Recurring & Recurring & Recurring \\
\hline Harvesting cycle & $7-9$ months & $\begin{array}{l}\text { Every 6 months } \\
\text { for 3 years }\end{array}$ & $\begin{array}{l}\text { Every year } \\
\text { for 3 years }\end{array}$ & $\begin{array}{l}\text { Every year } \\
\text { for 5 years }\end{array}$ \\
\hline Origin of planting stalk & Seeds & Seeds & Rhizome cuttings & Lower stem cuttings \\
\hline Planting material & 2000 & 500 & 32000 & 32500 \\
\hline Land Preparation cost & 1200 & 1200 & 3000 & 1200 \\
\hline Weed Management & 1500 & 3000 & 4000 & 6000 \\
\hline Sowing & 1000 & 2000 & 2500 & 3500 \\
\hline Fertilizer & 4000 & 5000 & 6000 & 6000 \\
\hline Harvesting & 3000 & 5000 & 6000 & 3000 \\
\hline $\begin{array}{l}\text { Post } \\
\text { harvest Management }\end{array}$ & 1500 & 2000 & 3000 & 8000 \\
\hline Total cost (Rs/acre) & $\mathbf{1 4 , 0 0 0}$ & $\mathbf{1 8 , 7 0 0}$ & $\mathbf{5 6 , 5 0 0}$ & $\mathbf{6 0 , 2 0 0}$ \\
\hline $\begin{array}{l}\text { Market rate/kg } \\
\text { Year -2015-16 }\end{array}$ & 40 & 35 & 70 & 100 \\
\hline $\begin{array}{l}\text { Yield per acre } \\
\text { (according to standardized } \\
\text { NMPB norms) }\end{array}$ & $\mathbf{7 0 0 ~ k g}$ & $\mathbf{1 5 0 0 - 2 0 0 0 \mathrm { kg }}$ & $1000-1500 \mathrm{~kg}$ & $\mathbf{1 2 0 0 ~ k g}$ \\
\hline Total income (Rs/acre) & $\mathbf{2 8 , 0 0 0}$ & $\mathbf{5 2 5 0 0}$ & $\mathbf{7 0 , 0 0 0}$ & $\mathbf{1 , 2 0 , 0 0 0}$ \\
\hline Economic benefit (Rs/acre) & $\mathbf{1 4 , 0 0 0}$ & $\mathbf{3 3 , 8 0 0}$ & $\mathbf{1 3 , 5 0 0}$ & $\mathbf{5 9 , 8 0 0}$ \\
\hline
\end{tabular}




\section{Phase 3 : Techniques for value addition and} investment scenario

In the trial plantation phase, some crops showed luxurious growth in the given experimental plots suggesting the suitability of that crop as a viable alternative. We could standardise the return on investment for these crop options. e.g. Kalmegh, Vekhand, Tulsi and Stevia.

Based on the data collected, the economics of these select species is given in Table 1 - all costs are in Rupees.

With further experimentation, we hope to finalise investment and return for other species like Citronella, Sonamukhi, Ashwagandha, Hadjodi and Vala, as we could see that they too have significant potential as plant crops for alternative livelihood.

With some crop options like Cissus sp. and Aspargus sp. we failed to get required growth in our experiment. So we could not conclude positively on few such species, which will need further investigation.

We then established a systematic approach in managing the alternative crops with the expertise provided by relevant experts in the medicinal plant field. The techniques of propagation, detailed cultivation methods, suggestions about raising of the planting stock, post planting treatments, manure/compost application, method of harvest, post-harvest management, and value addition techniques were developed as part of this phase. For the benefit of farmers, these were addressed in detail using the local language

Table 2 : Awareness and motivation workshops

\begin{tabular}{|l|l|l|l|l|}
\hline Sr No. & Dates & Participants & Activities & Discussion/Outcome \\
\hline 1 & May 2015 & 25 & $\begin{array}{l}\text { Common meeting for } \\
\text { promotion of the concept }\end{array}$ & $\begin{array}{l}\text { Farmers got to know for the first time } \\
\text { about such crops which are in high } \\
\text { trade (other than alternatives like } \\
\text { Haldi which they have known) }\end{array}$ \\
\hline 2 & 10 July 2015 & 50 & $\begin{array}{l}\text { Meeting with local NGO } \\
\text { and Biodiversity management } \\
\text { committee representatives }\end{array}$ & $\begin{array}{l}\text { Is the proposed model possible in } \\
\text { Tadoba fringe and what will be the } \\
\text { cost for such plantation }\end{array}$ \\
\hline 3 & $\begin{array}{l}8 \text { and 9th } \\
\text { May 2016 }\end{array}$ & 150 & $\begin{array}{l}\text { A workshop with farmers } \\
\text { having representation from } \\
\text { all villages }\end{array}$ & $\begin{array}{l}\text { Booklet with cultivation options was } \\
\text { released, buyback guarantors for small } \\
\text { crop yield visited this workshop }\end{array}$ \\
\hline
\end{tabular}

Table 3 : Experts who participated in the workshops

\begin{tabular}{|c|c|c|}
\hline Name of expert & Institute/NGO/Other affiliation & Expertise \\
\hline Dr. Rajendra Kale & Upvan & Buyback and cultivation of medicinal plants \\
\hline Dr. Vrinda Kate & Shri Shail Medi farms & Cultivation and planting stalk \\
\hline Poorva Joshi & Bio concepts & Medicinal plant trade and cultivation need \\
\hline Ambarish Ghatate & Ayurvan foundation & Cultivation, buyback \\
\hline Dr. Diwakar & $\begin{array}{l}\text { State Horticultural and } \\
\text { Medicinal Plant Board }\end{array}$ & Medicinal plants and role of government \\
\hline IISER facilitators & National Medicinal Plant board & $\begin{array}{l}\text { Grant options for individual farmers : Printed } \\
\text { information on various grants }\end{array}$ \\
\hline Vijay Dethe & Paryavaran mitra & $\begin{array}{l}\text { Biodiversity Management Committee, People's } \\
\text { Biodiversity Register, and community rights }\end{array}$ \\
\hline
\end{tabular}




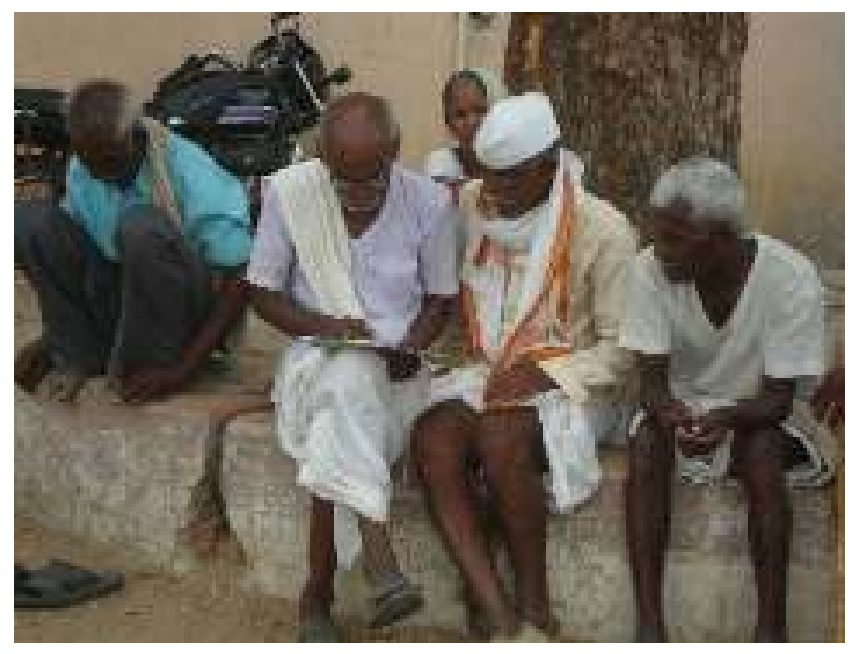

Figure 2 : Marathi booklet and information sharing

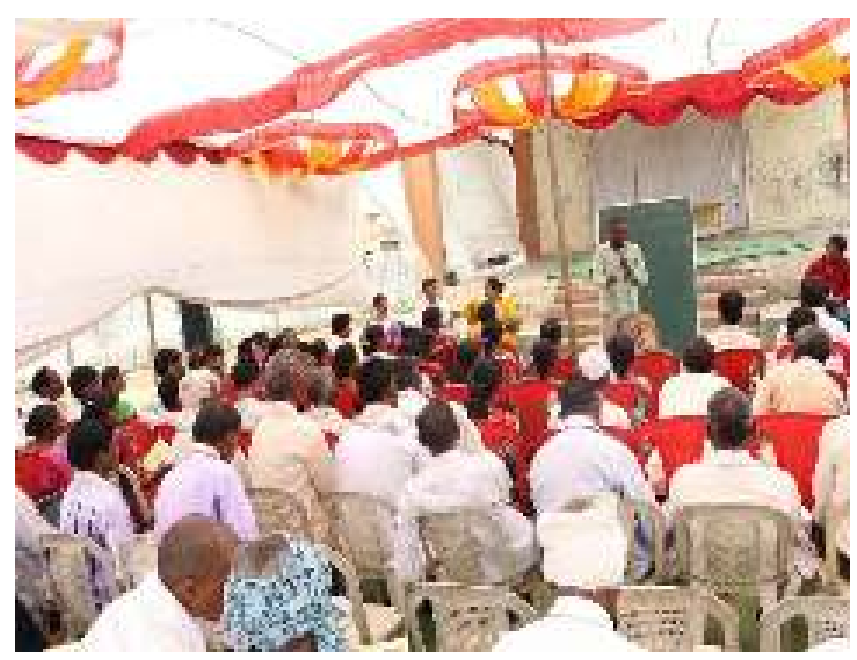

Figure 3: Workshop

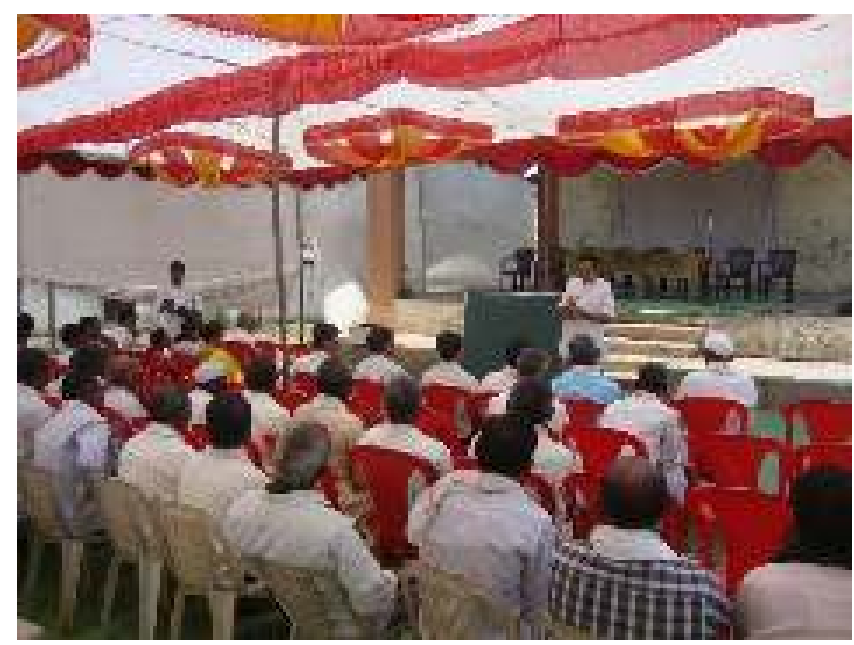

Figure 4: Training farmers

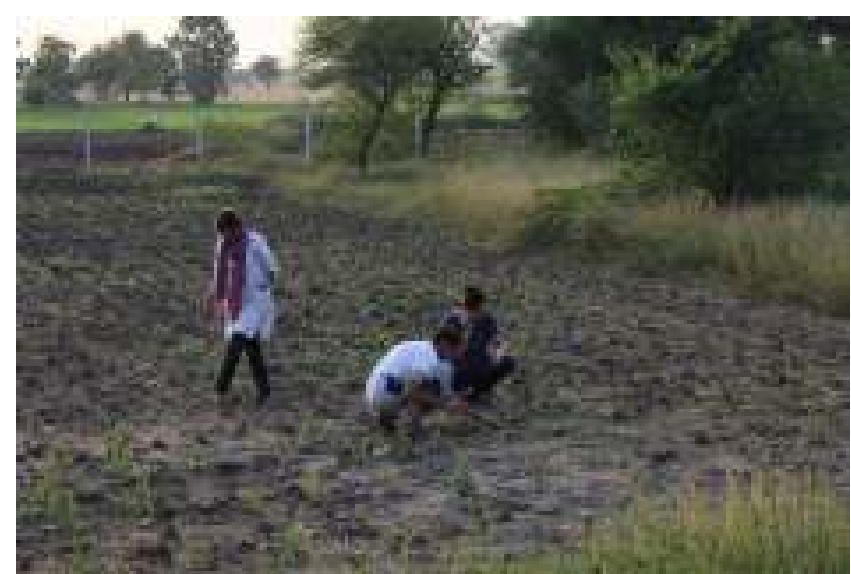

Figure 5 : Field training and technique standardization

(Marathi) in a booklet "Aushadhi vanaspatinche krushikaran : Ek garaj, Ek upay” (24).

\section{Phase 4 : Awareness and motivation program}

To disseminate the above information and to carry out meaningful interaction with locals we organized multiple workshops, facilitated by the research team. These workshops also helped us to validate and work through the suitability of the concept. The schedule, structure, and outcomes of these workshops are summarized in Table 2. The experts who participated in these workshops are listed in Table 3.

The booklet developed for these workshops will act as a tool that can be used to replicate this innovative and practical model for all forest fringes and creating best-practice guidelines. This booklet is developed with special focus on all local farmers as target audience. It gives all information related to cultivation methodology and buy back in the local language.

Figures 2-5 show a few glimpses of meaningful interactions during the workshops and fieldwork.

\section{Discussion and recommendations}

Owing to the vicinity of forests, buffer zones of Protected Areas have distinct advantages in agriculture such as good ground water levels and availability of green manure. The main problem of these areas is crop-raiding animals. The problem needs to be addressed at multiple levels including measures to reduce the damage, encouraging alternative crop species which are non-palatable to herbivores, along with alternative livelihood options (9). The innovative solution proposed here will help in supporting the current agriculture based livelihoods and also support conservation of wildlife by reducing human-wildlife conflicts. With simple value addition techniques, the 
produce can be made available for small scale medicinal industry establishing new employment strategies for the youths in such affected regions. Farmers can scale up the production if they form their own cooperative society and adopt appropriate post-harvest technologies, value addition and QPM (Quality Planting Materials) management. It is also possible to have purchase tie-ups with the herbal medicine industry.

It is expected that the venture will be independently run by the community after a certain period of intervention and guidance from the research team, thus improving their standard of living.

One major advantage of the TATR forest is that being a tiger reserve, it attracts a large number of tourists. Subsequently, selling some value-added produce from these medicinal herbs to tourists can provide additional business to the locals. For example, herbal tea or dried medicinal produce in packets can be sold to tourists.

The core concern of the study was to offer a solution to reduce the crop raiding and subsequently to provide economic alternative to the farmers to fulfil their livelihood necessities. So we developed a workable model that involves local people towards wildlife conservation and will contribute towards mitigating man-wildlife conflict issues. Our study addresses biodiversity conservation, human-animal conflict, rural development, crop raiding, employment strategies, diversification, and behavioural development of the community over their territory.

In this study, we also analysed the value chain for medicinal plants produced by village-based marginal farmers and homestead growers. We established linkages with buyers and made the information available to farmers (24). The booklet produced in this study addresses the distribution channels, purchase locations for seeds and fertilizer, water supply for the plants, technology inputs, etc. We also suggest an improved value chain system through economic coordination that links production with the enhancement of the producers' livelihoods. Through the research, we could do a market survey for the produce. With two potential buyers interested, we took forward the concept in a meeting between farmers and buyers. Commitment of buying the produce was offered by buyers. During this meeting, to avoid middlemen, buyers even promised farmers to the pick-up of primary processed harvest. With this successful intervention, now we want to help further in strengthening such linkages for the benefit of farmers.

As a future prospect, the diversification of this project and commencement of further research and development pertaining to this project will be initiated to sustain the livelihood option in the form of medicinal plant cultivation. This innovative enterprise may contribute in formalizing the informal medicinal plant sector in several ways. Policy supporting the formalization of such businesses and subsidies (a few are already available through National Medicinal Plant Board, Delhi for clusters of farmers) for medicinal plant growers in wildlife conflict areas may contribute to the betterment of these communities.

\section{Conclusion}

The research suggests that the diversification of agriculture in man-wildlife conflict areas will be useful for livelihood enhancement. A closer linkage between the producers and processors of medicinal plants through direct farmer participation could result in a multitude of benefits to both, in terms of price, quality, lead time and overall improvement of the supply chain.

This work will create awareness regarding alternative livelihood options in the form of non-palatable medicinal plant cultivation, and in meeting the demand of raw materials required for herbal medicine industries. This pilot study has provided an important starting point for research, training, and knowledge sharing about cultivation and post-processing practices of medicinal plants. It is important to develop and adopt these plants as a crop species to create a successful model for alternative livelihoods.

\section{References}

Arnold, J.E.M. and Perez, M.R. (2001) Can non-timber forest products match tropical forest conservation and development objectives? Ecological Economics, 39, 437-447.

Bayani and Watve (2015) Crop depredation by wild herbivores at the western boundary of TadobaAndhari Tiger Reserve (TATR) Chandrapur, Maharashtra, India. A comprehensive report submitted to The Department of Forest, Maharashtra State.

Bawa, K.S. and Gadgil, M. (1997) Ecosystem services in subsistence economics and conservation of biodiversity. In Nature's Services: Societal Dependence on Natural Ecosystems (ed.G.C. Daily), pp. 295-310.

Bayani A, Tiwade D, Dongre A, Dongre AP, Phatak R, Watve M (2016) Assessment of Crop Damage by Protected Wild Mammalian Herbivores on the Western Boundary of Tadoba-Andhari Tiger Reserve (TATR), Central India. PLoS ONE 11(4): 
e0153854. doi:10.1371/journal.pone.0153854

Caroline H., Medzhidov R. and Milner-Gulland E. J. (2011). Evaluating the relative effectiveness of alternative conservation interventions in influencing stated behavioural intentions: the saiga antelope in Kalmykia (Russia). Environmental Conservation 38 (1): 37-44.

Compendium of guidelines and circulars issued by Project Tiger directorate

Freya A. V. St John, Gareth Edwards-Jones A and Julia P. G. Jones (2010) Conservation and human behaviour: lessons from social psychology, Wildlife Research 37, 658-667

Fungo, B. A review of crop raiding around protected areas: Nature, control and research gaps. Environmental Research Journal 2011, 5(2):87-92.

Guerbois, C., Chapanda, E., and Frtiz, H., Combining multiscale socio-ecological approaches to understand the susceptibility of subsistence farmers to elephant crop raiding on the edge of protected areas. J. of App. Ecol. 2012, 49, 1149-1158.

Kala C.P., Farooquee, N.A. and Dhar, U. (2005) Traditional uses and conservation of timur (Zanthoxylum armatum) through social institutions in Uttaranchal Himalaya, India. Conservation and Society, 3, 224-230.

Karanth, K.K., Curran, L.M. and Reuning-Scherer, J.D. (2005) Village size and forest disturbance in Bhadra Wildlife Sanctuary, Western Ghats, India. Biological Conservation, 128, 147-157.

M. D. Madhusudan; (2003); Living Amidst Large Wildlife: Livestock and Crop Depredation by Large Mammals in the Interior Villages of Bhadra Tiger Reserve, South India; Environmental Management Vol. 31, No. 4, pg 466-475. 10. Lisa NaughtonTreves, Adrian Treves et al; (1998); Temporal patterns of crop raiding by Primates: linking food availability of crop lands and adjacent forest

Mahapatra, A.K., Albers, H.J. and Robinson, E.J.Z. (2005) The impact of NTFP sales on rural households' cash income in India's dry deciduous forest. Environmental Management, 35, 258-265.

Marshall, K. White, R., and Fischer, A., Conflicts between humans over wildlife management: on di- versity of stakeholder attitudes and implications for conflict management. Biodiversity Conservation 2007, 16,3129-3146.

Michael J. M. and Dayer A. A. (2004). Concepts for Exploring the Social Aspects of Human-Wildlife Conflict in a Global Context. Human Dimensions of Wildlife, 9:317-328.

Milind Watve, Abhijeet Bayani, Samriddha Ghosh (2016) Crop damage by wild herbivores: Insights obtained from optimization models. Current Science, v. 111, pp. 861-867

Milind Watve, Kajal Patel, Abhijeet Bayani and Pramod Patil (2016) A theoretical model of community operated compensation scheme for crop damage by wild herbivores, Global Ecol Conserv 5, 58-70.

Nagothu Udaya Sekhar (1998); Crop and Livestock depredation caused by wild animals in protected areas: The case of Sariska Tiger Reserve, Rajasthan, India;

Published booklet - Aushdhi vanaspatinche krushikaran - ek garaj ek upay, 5 June 2016

Rai, N.D. and Uhl, C.F. (2004) Forest product use, conservation and livelihoods: the case of Uppage fruit harvest in the Western Ghats, India. Conservation and Society, 2, 289-313.

Report ISBN: 92-9225-296-8 Secretariat of the Convention on Biological Diversity

Saterson, K., Christensen, N., Jackson, R., Kramer, R., Pimm, S., Smith, M. and Wiener, J. (2004) Disconnects in evaluating the relative effectiveness of conservation strategies. Conservation Biology 18: 597-599.

Sinha, A. and Bawa, K.S. (2002) Harvesting techniques, hemi parasites and fruit production in two non-timber forest tree species in south India. Forest Ecology and Management, 168, 289-300.

Sukumar, R., Ecology of the Asian elephant in southern India. II. Feeding habits and crop raiding patterns. J. of Trop. Ecol., 1990, 6,33-53.

Sutherland, M., Pullin, A., Dolman, P. and Knight, T. (2004) The need for evidence-based conservation. Trends in Ecology and Evolution 19: 305-308. 